Original Research Article

\title{
Self medication among medical and dental students in tertiary care teaching hospital of Udaipur, India
}

\author{
Hiren M. Chawda ${ }^{1}$, Ashwinkumar K. Panchasara ${ }^{2 *}$
}

${ }^{1}$ Department of Pharmacology, Pacific Medical College and Hospital, Udaipur, Rajasthan, India

${ }^{2}$ Department of Pharmacology, GMERS Medical College, Sola, Ahmedabad, Gujarat, India

Received: 09 June 2018

Accepted: 03 July 2018

\section{*Correspondence to: \\ Dr. Ashwinkumar K. \\ Panchasara, \\ Email: ashwin_panchasara@ yahoo.com}

Copyright: (C) the author(s), publisher and licensee Medip Academy. This is an openaccess article distributed under the terms of the Creative Commons Attribution NonCommercial License, which permits unrestricted noncommercial use, distribution, and reproduction in any medium, provided the original work is properly cited.

\begin{abstract}
Background: Self-medication involves acquiring and consuming medication without the advice of a physician and also resubmitting old prescriptions to purchase medicines. Inappropriate self-medication causes increase cost of therapy and incidence of adverse drug reactions. Self-medication was significantly higher among undergraduate medical and paramedical students in India. Objective of the study was to evaluate the prevalence of self-medication and perception towards self-medication among the undergraduate medical and dental students.
\end{abstract}

Methods: A pre-designed questionnaire collected the information pertaining to demographic details like age, gender, course, reason, pattern, indications, drugs used for self-medication. It also included questions concerning their attitude, perception and safety regarding self-medication.

Results: The prevalence of self - medication was 76.27\%. Larger numbers of females were self-medicating $(55.56 \%)$. The majority of the students' selfmedicated because of other advice $(92.59 \%)$, there was statistically significant difference between the male and female medical students to use a previous prescription for the same illness. A total of 136 (76.83\%) of the participants opined that self-medication was a part of self-care. Statistically significant differences between male and female students had been observed in safety variables like, "know side effects about your drug", "increasing drug dose can be dangerous" and "in case of side effects physicians' help must be sought". Cold and Cough was the most common $(60 \%)$ indication for self-medication.

Conclusions: The prevalence of self-medication was higher among females. The majority of the students' self-medicated because of other advice. The stringent policies should be required for medicines which can prevent the increasing trend of self-medicating.

Keywords: Dental students, India, Medical students, Self-medication

\section{INTRODUCTION}

William Osler told that an immense characteristic which distinguishes human from animals is the craving to take medicine. ${ }^{1}$ Self-medication involves acquiring and consuming medication without the advice of a physician and also resubmitting old prescriptions to purchase medicines, sharing medicines with relatives or using leftover medicines stored in house. ${ }^{2}$ Thus, self-medication is a part of self-care which includes first aid on a daily basis life, non-drug self-treatment and social support in illness. $^{3}$ The social media promote self-medication activities and the youth are highly influenced by them. ${ }^{4}$ Due to increased advertising of pharmaceutical products, they are the larger threats to the youth who involve in selfmedication which increases issues like incorrect selfdiagnosis, drug interaction and misuse of drugs for false indications..$^{5}$ Inappropriate self-medication causes increase 
cost of therapy, resistance of pathogens and incidence of adverse drug reactions, thus self-medication increases morbidity. ${ }^{6-9}$ Misuses of medicines are increased due to easy availability of pharmaceutical products globally. Self-medication is a common practice among a group of health workers in Nigeria, according to Ehigiator O et al. ${ }^{10}$ Undergraduate medical and paramedical students have easy access to information about pharmaceuticals from drug indices, literature and social media. ${ }^{11}$ A previous study from All India Institute of Medical Sciences, New Delhi reported that self-medication was significantly higher among undergraduate medical and paramedical students in India and it increased due to their medical acquaintance. ${ }^{12}$ Hence, the present study was conducted to evaluate the prevalence of self-medication and perception towards self-medication among the undergraduate medical and dental students of the Pacific Medical College, Udaipur, Rajasthan, India.

\section{METHODS}

Ethical approval was obtained from the Institutional Ethics Committee of Pacific Medical College and Hospital, Udaipur, India prior to the start of the study. This crosssectional study was carried out among the first year medical and dental undergraduate students of Pacific Medical College, Udaipur during 2017. The sample size was calculated assuming with a 5\% margin of error, 50\% response rate, 250 population size and $95 \%$ confidence interval, so 152 participants were calculated by using an online sample size calculator (Raosoft). Informed consent was taken of each student before participating in the study. A pre-designed questionnaire was used to collect the relevant information from undergraduates. The information pertaining to demographic details like age, gender, course, reason, pattern, indications, drugs used for self-medication were included in the questionnaire. It also included questions concerning their attitude, perception and safety regarding self-medication. The investigator was present in case the respondents required assistance about the questionnaire. The students who did not self-medicate was instructed to fill questions about demographic details, attitude and safety regarding self-medication. The questionnaires were assessed for their completeness and only the completed questionnaires were considered in the final analysis in this study. The collected data was analyzed by using GraphPad Instat 3.0 (Trial Version). The results obtained were expressed in proportions. Fisher's exact test was used for testing the statistical significance. $\mathrm{P}<0.05$ was considered as statistically significant.

\section{RESULTS}

A total of 177 students was assessed regarding their practice, attitude and perception regarding self-medication behavior, out of which $47.46 \%(n=84)$ were males and $52.54 \%(n=93)$ were females. The prevalence of selfmedication among the study participants was $76.27 \%$ $(n=135)$. A proportionately larger number of females were self-medicating $(n=75,55.56 \%)$ than males $(n=60$, $44.44 \%$ ) which was statistically not significant (Table 1).

Table 1: Demographic data of the participants.

\begin{tabular}{|c|c|c|c|c|}
\hline \multirow{2}{*}{ Characteristics } & \multirow{2}{*}{$\begin{array}{l}\text { Medical } \\
\text { student } \\
(\%)\end{array}$} & \multirow{2}{*}{$\begin{array}{l}\text { Dental } \\
\text { student } \\
(\%)\end{array}$} & \multicolumn{2}{|c|}{$\begin{array}{l}\text { Self-medicated } \\
\text { student }(\%)\end{array}$} \\
\hline & & & $\begin{array}{l}\text { Medical } \\
\text { student }\end{array}$ & $\begin{array}{l}\text { Dental } \\
\text { student }\end{array}$ \\
\hline Male & $\begin{array}{l}69 \\
(38.9)\end{array}$ & $15(8.5)$ & $\begin{array}{l}48 \\
(69.5)\end{array}$ & $12(80)$ \\
\hline Female & $\begin{array}{l}54 \\
(30.5)\end{array}$ & $39(22)$ & $\begin{array}{l}43 \\
(79.6)\end{array}$ & $32(82)$ \\
\hline Total $(\mathrm{n}=177)$ & $\begin{array}{l}123 \\
(69.5)\end{array}$ & $\begin{array}{l}54 \\
(30.5)\end{array}$ & $\begin{array}{l}91 \\
(73.9)\end{array}$ & $\begin{array}{l}44 \\
(81.5)\end{array}$ \\
\hline
\end{tabular}

Figures indicate numbers with percentages in parentheses

Table 2: Reasons for self-medication.

\begin{tabular}{|lllllll|}
\hline \multirow{2}{*}{ Reason } & Medical student & & \multicolumn{2}{c|}{ Dental student } \\
& $\begin{array}{l}\text { Male } \\
\mathbf{4 8}\end{array}$ & $\begin{array}{l}\text { Female } \\
\mathbf{( 4 3 )}\end{array}$ & $\begin{array}{l}\text { Total } \\
\mathbf{( 9 1 )}\end{array}$ & $\begin{array}{l}\text { Male } \\
(\mathbf{1 2})\end{array}$ & $\begin{array}{l}\text { Female } \\
\mathbf{( 3 2})\end{array}$ & $\begin{array}{l}\text { Total } \\
\mathbf{( 4 4 )}\end{array}$ \\
\hline It is time saving & 41 & 35 & 76 & 12 & 28 & 40 \\
\hline Want to avoid OPD crowd & 21 & 22 & 43 & 06 & 16 & 22 \\
\hline Want to avoid Fees & 10 & 06 & 16 & 04 & 07 & 11 \\
\hline Because someone advice & 43 & 41 & 84 & 12 & 29 & 41 \\
\hline Acquired knowledge from social media & 29 & 32 & $61^{* *}$ & 05 & 12 & 17 \\
\hline Can manage such symptoms on my own & 46 & 40 & $86^{\#}$ & 10 & 26 & 36 \\
\hline Due to prescription failure & 07 & 05 & 12 & 00 & 04 & 04 \\
\hline Feel uncomfortable with physician & 02 & 05 & 07 & 02 & 06 & 08 \\
\hline Using previous prescription for same illness & 23 & $30^{*}$ & 53 & 09 & 20 & 29 \\
\hline Confidence in self diagnosis & 39 & 30 & 69 & 07 & 20 & 27 \\
\hline
\end{tabular}

$\mathrm{P}<0.05$ as compared to male medical students (Chi-square test); ${ }^{* *} \mathrm{P}<0.05$ as compared to dental students (Fisher's exact test); ${ }^{\text {}} \mathrm{P}<0.05$ as compared to dental students (Fisher's exact test). 
The majority of the students self-medicated because of other's advice (92.59\%), followed by their confidence about managing the symptom by themselves (90.37\%), followed by it's time saving process $(85.92 \%)$. There was statistically significant difference between the male and female medical students to use a previous prescription for the same illness $(\mathrm{P}=0.03)$. "Acquired knowledge from social media" $(\mathrm{P}=0.002)$ and "Can manage such symptoms my own" $(\mathrm{P}=0.02)$ were statistically significant reasons between medical and dental students (Table 2).

However, for other reasons the differences were not statistically significant between male and female of medical and dental students, also it was not significant between medical and dental students (Table 2).

The attitude of medical and dental students towards the practice of self-medication was shown in Table 3. A total of $136(76.83 \%)$ of the participants opined that selfmedication was a part of self-care. $44.06 \%$ of the participants want to advise self-medications to others. However, Students' attitude towards self-medication; the differences were not statistically significant between male and female students.

Table 3: Students attitude towards self-medication.

\begin{tabular}{|lllll|}
\hline \multirow{2}{*}{ Items } & \multicolumn{2}{l}{ Male (84) } & \multicolumn{2}{l|}{ Female } \\
\cline { 2 - 5 } & $\begin{array}{l}\text { Yes } \\
(\mathbf{\%})\end{array}$ & $\begin{array}{l}\text { No } \\
(\mathbf{\%})\end{array}$ & $\begin{array}{l}\text { Yes } \\
(\mathbf{\%})\end{array}$ & $\begin{array}{l}\text { No } \\
(\mathbf{\%})\end{array}$ \\
\hline $\begin{array}{l}\text { Self-medication is } \\
\text { a part of self-care }\end{array}$ & $\begin{array}{l}64 \\
(76.2)\end{array}$ & $\begin{array}{l}20 \\
(23.8)\end{array}$ & $\begin{array}{l}72 \\
(77.4)\end{array}$ & $\begin{array}{l}21 \\
(22.6)\end{array}$ \\
\hline $\begin{array}{l}\text { Continue with/ } \\
\text { start self } \\
\text { medication }\end{array}$ & 60 & 24 & 75 & 18 \\
\hline $\begin{array}{l}\text { Want to stop self- } \\
\text { medication }\end{array}$ & 24 & 60 & 18 & 75 \\
\hline $\begin{array}{l}\text { Advice self- } \\
\text { medication to }\end{array}$ & $(28.6)$ & $(71.4)$ & $(19.4)$ & $(80.6)$ \\
Friends & $(50)$ & 42 & 36 & 57 \\
\hline
\end{tabular}

According to Table 4, statistically significant differences between male and female students had been observed in safety variables like, "know side effects about your drug" $(\mathrm{P}=0.004)$, "increasing drug dose can be dangerous" $(\mathrm{P}=$ $0.02)$ and "in case of side effects physicians' $(\mathrm{P}=0.04)$ help must be sought". Details of the views regarding safety of self-medication were presented in Table 4.

However, for other variables regarding safety views of self -medication, the differences were not statistically significant between male and female students.

Cold and Cough was the most common (60\%) indication for self-medication, followed by headache $(59.2 \%)$ and fever $(51.8 \%)$. Renal stones $(0.7 \%)$ were the least common cause for self-medication which is shown in Table 5. Types of self-medications commonly practiced among undergraduate students were shown in Table 6.
Table 4: Students' view about safety of self-medication.

\begin{tabular}{|c|c|c|c|c|}
\hline \multirow{2}{*}{ Items } & \multicolumn{2}{|c|}{ Male (84) } & \multicolumn{2}{|c|}{ Female (93) } \\
\hline & Yes & No & Yes & No \\
\hline $\begin{array}{l}\text { Self-medication } \\
\text { is safe }\end{array}$ & $\begin{array}{l}35 \\
(41.7)\end{array}$ & $\begin{array}{l}49 \\
(58.3)\end{array}$ & $\begin{array}{l}42 \\
(45.2)\end{array}$ & $\begin{array}{l}51 \\
(54.8)\end{array}$ \\
\hline $\begin{array}{l}\text { Know side effects } \\
\text { about your drug }\end{array}$ & $\begin{array}{l}41 \\
(48.8)\end{array}$ & $\begin{array}{l}43 \\
(51.2)\end{array}$ & $\begin{array}{l}65^{*} \\
(69.9)\end{array}$ & $\begin{array}{l}28 \\
(30.1)\end{array}$ \\
\hline $\begin{array}{l}\text { Ayurvedic drugs } \\
\text { have not side } \\
\text { effects }\end{array}$ & $\begin{array}{l}58 \\
(69)\end{array}$ & $\begin{array}{l}26 \\
(31)\end{array}$ & $\begin{array}{l}57 \\
(61.3)\end{array}$ & $\begin{array}{l}36 \\
(38.7)\end{array}$ \\
\hline $\begin{array}{l}\text { Simultaneous use } \\
\text { of two drugs can } \\
\text { be potentially } \\
\text { dangerous }\end{array}$ & $\begin{array}{l}72 \\
(85.7)\end{array}$ & $\begin{array}{l}12 \\
(14.3)\end{array}$ & $\begin{array}{l}85 \\
(91.4)\end{array}$ & $\begin{array}{l}08 \\
(8.6)\end{array}$ \\
\hline $\begin{array}{l}\text { Increasing drug } \\
\text { dose can be } \\
\text { dangerous }\end{array}$ & $\begin{array}{l}79 \\
(94)\end{array}$ & $05(6)$ & $\begin{array}{l}93^{* *} \\
(100)\end{array}$ & $\begin{array}{l}00 \\
(00)\end{array}$ \\
\hline $\begin{array}{l}\text { Lowering drug } \\
\text { dose can be } \\
\text { dangerous }\end{array}$ & $\begin{array}{l}38 \\
(45.2)\end{array}$ & $\begin{array}{l}46 \\
(54.8)\end{array}$ & $\begin{array}{l}32 \\
(34.4)\end{array}$ & $\begin{array}{l}61 \\
(65.6)\end{array}$ \\
\hline $\begin{array}{l}\text { In case of side } \\
\text { effects } \\
\text { physicians' help } \\
\text { must be sought }\end{array}$ & $\begin{array}{l}80 \\
(95.2)\end{array}$ & $\begin{array}{l}04 \\
(4.8)\end{array}$ & $\begin{array}{l}93^{\#} \\
(100)\end{array}$ & $\begin{array}{l}00 \\
(00)\end{array}$ \\
\hline $\begin{array}{l}\text { Branded drugs } \\
\text { are more safe }\end{array}$ & $\begin{array}{l}65 \\
(77.4) \\
\end{array}$ & $\begin{array}{l}19 \\
(22.6)\end{array}$ & $\begin{array}{l}67 \\
(72.04)\end{array}$ & $\begin{array}{l}26 \\
(2.8)\end{array}$ \\
\hline $\begin{array}{l}\text { Want to take } \\
\text { medicine by } \\
\text { brand name }\end{array}$ & $\begin{array}{l}47 \\
(56)\end{array}$ & $\begin{array}{l}37 \\
(44)\end{array}$ & $\begin{array}{l}59 \\
(63.4)\end{array}$ & $\begin{array}{l}34 \\
(36.6)\end{array}$ \\
\hline
\end{tabular}

${ }^{*} \mathrm{P}<0.05$ as compared to male students (Fisher's exact test); ${ }^{* *} \mathrm{P}$ $<0.05$ as compared to male students (Fisher's exact test); ${ }^{\mathrm{P}}<0.05$ as compared to male students (Fisher's exact test)

Table 5: Indications for self-medication $(\mathbf{N}=135)$.

\begin{tabular}{|ll|}
\hline Indications & $\mathbf{N}(\%)$ \\
\hline Cold and Cough & $81(60)$ \\
\hline Headache & $80(59.2)$ \\
\hline Fever & $70(51.8)$ \\
\hline Acidity & $34(25.2)$ \\
\hline Vomiting & $28(20.7)$ \\
\hline Abdominal Pain & $24(17.8)$ \\
\hline Diarrhoea & $22(16.3)$ \\
\hline Sore throat & $21(15.6)$ \\
\hline Menstrual symptoms & $21(15.6)$ \\
\hline Muscular or joint pain & $19(14.07)$ \\
\hline Weakness & $16(11.85)$ \\
\hline Ulcer in mouth & $11(8.1)$ \\
\hline Renal stones & $01(0.7)$ \\
\hline
\end{tabular}

\section{DISCUSSION}

Self-medication defined as the utilization of drugs to manage self-diagnosed health complaints or the usual use of a prescribed drug for acute or chronic disease manifestations. ${ }^{13-15}$ According to World Health 
Organization, "self-medication is the selection and use of medicines by individuals to treat self-recognized illnesses or symptoms."16 Self-medication is considered a constituent of self-care. ${ }^{16}$ People have always been keen to accept more individual responsibility for their own health status and so, self-medication has been a characteristic of the healthcare system since many years. ${ }^{16,17}$ Selfmedication has many pros and cons and it's depend on who and what one decided to take it. ${ }^{18}$ The present study was conducted to evaluate the prevalence of self-medication and perception towards self-medication among the undergraduate medical and dental students of Pacific Medical College, Udaipur, Rajasthan, India.

Table 6: Type of self-medication commonly practiced by the participants.

\begin{tabular}{|ll|}
\hline Types of self-medication & $\mathbf{N}(\%)$ \\
\hline Over the counter drugs & $90(66.7)$ \\
\hline Homeopathic drugs & $28(20.7)$ \\
\hline Ayurvedic drugs & $20(14.8)$ \\
\hline Slimming diet & $04(2.9)$ \\
\hline Remedies for muscle mass gain & $01(0.7)$ \\
\hline
\end{tabular}

The prevalence of self-medication in this study was found to be $76.27 \%$ as compared to Kumar $\mathrm{N}$ et al. ${ }^{19}$ The prevalence of self-medication among the medical students from India was shown to be ranging between $57.1 \%$ and $92 \%$ as compared to non-medical students were $80.1 \%$ in other studies. ${ }^{20-23}$ The prevalence of self-medication was shown to be $25.4 \%$ and $43.2 \%$ in Ethiopia, $51 \%$ in Slovenia, $55.3 \%$ in Pakistan, 55\% in Egypt, $56.9 \%$ in Nigeria and $80.9 \%$ in Malaysia. ${ }^{24-30}$ Gender is considered as a significant factor in self-medication patterns among undergraduate students. ${ }^{19}$ In the current study, the prevalence of self-medication was observed to be higher among females as same as other studies from India and overseas countries..$^{20,22,26}$ Allopathic system of medicine was mostly followed system as compared to other and it was similar finding observed in other studies. ${ }^{31,32}$

The majority of the students' self-medicated because of other advice, followed by their confidence about manage the symptom themselves and it's time saving process as compared to coastal south et al where a reason for selfmedication was illness is too minor. ${ }^{19}$ However, another study from Tamil Nadu the most common reason for selfmedication was time saving, whereas in Punjab was for quick relief. ${ }^{23,32}$ Previous prescription for the same illness was reported as the most common source of information about the drugs used for self-medication. ${ }^{19,23,32}$ In current study, the use of the previous prescription for the same illness was more prevalent in female medical students than male medical students (Table 2). Most common indication for self-medication in this study was cold and cough, which was similar finding in other studies from western and southern part of India. ${ }^{20,22}$ Other studies reported fever as the most common indication for self-medication. ${ }^{19,24}$ In the current study, $76.8 \%$ of the participants felt that selfmedication was part of self-care which was higher to that reported in other studies from Southern India, Ethiopia and Karachi. ${ }^{19,25,27}$ As compared to southern et al, 76\% of the participants wished to continue with self-medication which was higher than it. ${ }^{19}$ In this study, $44.06 \%$ of the participants want to advise self-medications to others as compared to other. ${ }^{19}$ The irrational utilization of drugs is a cause of public as well as a professional concern. ${ }^{3}$ Selfmedication can be defensible when there is a legal use of medicines. Self-medication has concern with many threats like using expired drugs, sharing them with friends or taking medicine that have been originally prescribed for some other indications, accidental drug poisoning. Selfmedication also invites hazards such as drug dependence, adverse reaction and antimicrobial resistance. Antimicrobial resistance is another universal problem, particularly in developing countries where antimicrobials are often available without a prescription. ${ }^{33}$

The current study findings are based on a single centre hence, the study observations cannot be generalized. If we want to know various factors influencing the people for self-medication, we will be needed more multi-centric studies in India.

\section{CONCLUSION}

The current study concluded that the prevalence of selfmedication was higher among females. The majority of the students' self-medicated because of other advice. Higher numbers of students felt that self-medication was part of self-care and wished to continue with it. Our study distinguishes that stringent policies should be required for medicines which can prevent the increasing trend of selfmedicating.

\section{Funding: No funding sources Conflict of interest: None declared \\ Ethical approval: The study was approved by the Institutional Ethics Committee of Pacific Medical College and Hospital, Udaipur, India}

\section{REFERENCES}

1. Cushing H. The life of Sir William Osler. $2^{\text {nd }}$ Ed. Oxford: Oxford University Press; 1925.

2. Guidelines for the regulatory assessment of medicinal products for use in Self medication, WHO; 2000. Available

at: http://apps.who.int/medicinedocs/pdf/s2218e/s2218e. pdf. Accessed: 2013 Feb 26.

3. Loyola Fil ho AI, Lima-Costa MF, Uchoa E. Bambuí project: a qualitative approach to self-medication. Cad Saude Publica. 2004;20:1661-9.

4. Klemenc-Ketis Z, Hladnik Z, Kersnik J. A cross sectional study of sex differences in self-medication practices among university students in Slovenia. Coll Antropol. 2011;35:329-34.

5. Burak LJ, Damico A. College students' use of widely advertised medications. J Am Coll Health. 2000;49:118-21. 
6. James H, Handu SS, Khalid AJ, Khaja A, Otoom S, Sequeira RP. Evaluation of the knowledge, attitude and practice of self-medication among first-year medical students. Med Princ Pract. 2006;15:270-5.

7. Hughes CM, McElnay JC, Fleming GF. Benefits and risks of self-medication. Drug Saf. 2001;24:1027-37.

8. Hem E, Stokke G, Reidar TR, Grønvold NT, Vaglum P, Ekeberg O. Self-prescribing among young Norwegian doctors: a nine-year follow-up study of a nationwide sample. BMC Med. 2005;3:16.

9. Kiyingi KS, Lauwo JAK. Drugs in home: danger and waste. World Health Forum. 1993;14:381-4.

10. Ehigiator O, Azodo CC, Ehizele AO, Ezeja EB, Ehigiator L, Madukwe IU. Self-medication practices among dental, midwifery and nursing students. Eur $\mathbf{J}$ Gen Dentistry. 2013;2:54-7.

11. Badiger S, Kundapur R, Jain A, Kumar A, Pattanshetty S, Thakolkaran, et al. Self-medication pattern among medical students in South India. AMJ. 2012;5:217-20.

12. Self-medication popular among medical students. AIIMS study. Available at: http://www.livemint.com/Politics/XcN44QD5g8aW4 dwltcUdtI/Selfmedicationpopular among-medicalstudents-AIIMS-study.html. Accessed 27 Feb 2013.

13. Bekele BB, Berkesa ST, Tefera E, Kumalo A. SelfMedication Practice in Limmu Genet, Jimma Zone, Southwest Ethiopia: Does Community Based Health Insurance Scheme Have an Influence? J Pharma. [Internet]. February 2018:8. Available at: https://www.hindawi.com/journals/jphar/2018/17491 $37 /$.

14. Tenaw A, Tsige GM. Self-medication practices in Addis ababa: a prospective study. Ethiop J Health Sci. 2004;14:1-11.

15. World Health Organization, Guidelines for the Regulatory Assessment of Medicinal Products for Use in Self-Medication, in World Health Organization, World Health Organization; 2000.

16. The Role of the Pharmacist in Self-Care and SelfMedication. Available at: http:// apps.who.int/medicinedocs/pdf/whozip32e/whozip32 e.pdf Accessed: 2013 Feb 27.

17. Joint Statementby the International Pharmaceutical Federation and The World Self-Medication Industry. Available at: http://www.fip.org/www/uploads/database_file.php?i d =241andtable_id. Accessed: 2013 Feb 27.

18. Dangers of Self-Medication. Available at: http://www.healthguidance.org/entry /15933 /1/Dangers-of-Self-Medication.html. Accessed: 2013 Feb 28.

19. Kumar N, Kanchan T, Unnikrishnan B, Rekha T, Mithra P, Kulkarni V, et al. Perceptions and Practices of Self-Medication among Medical Students in Coastal South India. PLoS ONE, 2013;8:1-5.

20. Banerjee I, Bhadury T. Self-medication practice among undergraduate medical students in a tertiary care medical college, West Bengal. J Postgrad Med. 2012;58:127-31.

21. Sontakke SD, Bajait CS, Pimpalkhute SA, Jaiswal KM, Jaiswal SR. Comparative study of evaluation of self-medication practices in first and third year medical students. Int J Biol Med Res. 2011;2:561-64.

22. Badiger S, Kundapur R, Jain A, Kumar A, Pattanshetty S, Thakolkaran N, et al. Self-medication patterns among medical students in South India. Australas Med J. 2012;5:217-20.

23. Kayalvizhi S, Senapathi R. Evaluation of the perception, attitude and practice of self-medication among business students in 3 select cities, South India. IJEIMS. 2010;1:40-4.

24. Abay SM, Amelo W. Assessment of self-medication practices among medical, pharmacy, and health science students in Gondar University, Ethiopia. J Young Pharm. 2010;2:306-10.

25. Gutema GB, Gadisa DA, Kidanemariam ZA, Berhe DF, Berhe AH, Hadera MG, et al. Self-Medication Practices among Health Sciences Students: The Case of Mekelle University. J Appl Pharmaceutical Sci. 2011;1:183-9.

26. Smogavec M, Softic $`$ N, Kersnik J, Klemenc-Ketis` Z. An overview of self treatment and self-medication practices among Slovenian citizens. Slovenian Med J. 2010;79:757-63.

27. Zafar SN, Syed R, Waqar S, Irani FA, Saleem S. Prescription of medicines by medical Students of Karachi, Pakistan: a cross-sectional study. BMC Public Health. 2008;8:162-8.

28. El Ezz NF, Ez-Elarab HS. Knowledge, attitude and practice of medical students towards self-medication at Ain Shams University, Egypt. J Prev Med Hyg. 2011;52:196-200.

29. Fadare JO, Tamuno I. Antibiotic self-medication among university medical undergraduates in Northern Nigeria. J Public Health Epidemiol. 2011;3:217-20.

30. Ali SE, Ibrahim MIM, Palaian S. Medication storage and self-medication behaviour amongst female students in Malaysia. Pharm Pract. 2010;8:226-32.

31. Verma RK, Mohan L, Pandey M. Evaluation of self medication among professional students in North India: proper statutory drug control must be implemented. Asian J Pharmaceutical Clin Res. 2010;3:60-4.

32. Gupta V, Bansal P, Manhas R, Singh Z, Ghaiye P. Preferred system of medicine and reasons of selfmedication among college students in Malwa region of Punjab. J Drug Deliv and Ther. 2011;1:27-9.

33. Sarkar P, Gould IM. Antimicrobial agents are societal drugs: how should this influence prescribing? Drugs. 2006;66:893-901.

Cite this article as: Chawda HM, Panchasara AK. Self medication among medical and dental students in tertiary care teaching hospital of Udaipur, India. Int J Basic Clin Pharmacol 2018;7:1637-41. 